\title{
A Study on Fodder Technological Options for Improving Livestock Production in Karnataka
}

\author{
P. Pushpa*, B. S. Lakshman Reddy, Jayalakshmi B. Pawar, \\ K. Chandan and S. B. Gurumurthy \\ University of Horticultural Sciences, Bagalkot, Karnataka, India \\ *Corresponding author
}

\begin{abstract}
A B S T R A C T
Keywords

Fodder Technology,

Livestock

Production

Article Info

Accepted:

20 October 2020

Available Online:

10 November 2020

Livestock sector plays an important role in the national economy and in the socioeconomic development of the country. Green fodder provides nutrients for milch animals at cheaper cost. Inspite of its importance, in the country, green fodder production has not been given proper place in the cropping pattern in providing proper nutrition to livestock. In view of this, a study was undertaken to analyse the feed and fodder management systems in periurban and rural areas of Belgaum district. Totally 160 respondents of 8 villages in periurban and rural areas was interviewed by administering the standardised interview schedule the availability of DCP in rural areas was only $0.474 \mathrm{~kg} / \mathrm{head} / \mathrm{day}$ leading to a percentage deficiency of 36.8. In rural areas the availability of TDN was only $2.065 \mathrm{~kg} /$ head/day and the same was $3.868 \mathrm{~kg} / \mathrm{head} /$ day in peri-urban areas the deficiency of DCP was observed in both rural $(81.42 \%)$ and peri-urban areas (75.89). Considerable percentage deficiency was observed in TDN of feeds and fodder fed to livestock in rural $(93.06 \%)$ and peri-urban areas $(73.71 \%)$. The variables Land holding, Herd size, Milk volume, Income from agriculture and Income from livestock showed positive and significant relationship with fodder management.
\end{abstract}

\section{Introduction}

Green fodder plays an important role in dairying. The sustainability of the livestock production system in the country is handicapped due to perpetual shortage of feed and fodder even though the livestock industry by and large dependent on agricultural residues, waste materials and naturally available green fodder. Green fodder plays an important role in dairying. The term green fodder applies to those crops which are used to supply the roughages necessary in rations for farm animals and which are suitable for use as green fodder. Green fodder provides nutrients for milch animals at cheaper cost. In spite of its importance, in the country, green fodder production has not been given proper place in the cropping pattern in providing proper nutrition to livestock. At this juncture, it should be noted that only 3.5 per cent of cultivable land of the country is allotted for green fodder production.

Fodder plays an important role in economizing the cost of milk production. 
Fodder comprises a major protein of dairy ration of milch animals and therefore cultivation of nutritious and high yielding fodder is inevitable. Profitable livestock farming depends mainly on availability of fodder. With increase in number of animal population \& shrinking land resources, the problem to provide adequate feed and forage is becoming acute. According to Government of India planning commission during 2002-03 the total fodder production in India was 88.08 thousand tons.

In 2005 supply of green and dry fodder in India was 389.9 million tons and 443 million tons, respectively. Where as demand for green fodder was 1025 million tons and dry fodder was 569 million tons. Hence the green fodder was deficit by 61.961 percent and dry fodder was deficit by 22.081 percent.

Insufficient availability of fodder is thus one of the major constraints of livestock rearing in the country. This calls for organized efforts to enhance the availability of fodder utilizing scientific fodder production and management techniques. The present study concentrated on developing fodder technological options for improving livestock production that would facilitate for more effective analysis and discussion on fodder management systems in rural and peri-urban areas.

\section{Brief description of the study area}

The district is located in the north-western part of the state. It lies between $15^{\circ} 23^{\prime}$ to $16^{\circ} 58^{\prime}$ 'north latitude and $74^{\circ} 5^{\prime}$ to $75^{\circ} 28^{\prime}$ ' east longitude. The most elevated portion of the district lies to the west and south along the line of the Sahyadri hills. The district is between 450 to $900 \mathrm{~m}$. above mean sea level and extends over an area of 13,379 sq km which is 6.99 per cent of total geographical area of the state. Total geographical area of the district is 87087 ha. Rural population was
$3,194,848$ and urban population was $1,012,416$ total population of Belgaum district was 4,207,264 in 2001. Average rainfall of the district is $762 \mathrm{~mm}$.

The total bovine population of the district was 1208779 in 2003 and total buffaloes population was 701196. The main food crops of the district are jowar, paddy and wheat. Commercial crops like cotton, tobacco, groundnut and sugarcane are also raised in the district.

Four villages that are located less than $8 \mathrm{kms}$ from the district headquarter were selected as periurban areas. Belgaum district veterinary officers were also consulted while finalizing these villages. Another four villages which are located beyond $8 \mathrm{kms}$ from the district headquarter are selected as rural areas. The study hence covered 8 villages. The names of the villages selected along with their general description is presented in table 1

\section{Materials and Methods}

Study was conducted in Belgaum district of Karnataka state, as it ranks first in terms of total livestock population. Sample was drawn from periurban and rural areas. Periurban refers to an area or village or habitation located in the perimeter of the urban area having partial or complete influence of urbanization. Four villages that are located within a distance of $8 \mathrm{~km}$ from district headquarter with partial influence of urbanization were selected as periurban areas. Another 4 villages located beyond $8 \mathrm{~km}$ were selected for rural areas. Thus the study covered totally 8 villages. Possession of livestock was the main criterion used to select the respondents. In each selected village, 20 respondents were randomly interviewed. The study covered 80 farmers from periurban area and 80 from rural area totalling to 160 farmers. 
The data was collected through personal interview technique. Interview schedule was designed incorporating all the identified variables and was tested at three different stages to identify the ambiguities and to standardised the interview schedule. This standardised interview schedule was used to collect the data from the respondents.

\section{Technological options available to improve the livestock production systems}

Two systems were identified in the process of collecting data from the respondents. Those were intensive livestock production system under irrigated conditions and fodder production in rainfed system. Seven most important technological options available to each of these systems were listed by consulting the scientists in fodder production technologies.

The responses of ten experts working in the concerned field for each of these technologies were sought against three point continuum as most appropriate, appropriate and less appropriate.

The number of scientists considering the listed technological options as most appropriate, appropriate or less appropriate to improve the livestock production system was worked out.

\section{Constraints encountered in feed and fodder management}

The problems encountered by the respondents while managing feed and fodder were collected by open end questions. The problems expressed by the respondents were then grouped under 8 broad heads. The frequency and percentages were calculated for each of the problem separately for rural and peri urban respondents.

\section{Results and Discussion}

\section{Fodder technological options for improving livestock production system}

Table 2 depicts fodder technological options for improving livestock production system. Out of 10 scientists, 8 scientists were of the opinions that inter cultivation of improved perennial grasses and improved perennial legumes was most appropriate method in intensive livestock production system. For the same system, cultivation of improved perennial grasses and also annual fodder crops like sorghum, maize in the field was suggested by 6 scientists as appropriate method. Cultivation of only improved hybrid Napier grass was regarded as the less appropriate technology by majority scientists. This is due to the fact that annual fodder crops if grown would meet out the quantity requirement besides providing stover to stack for off season utilisation.

Out of 10 scientists, 7 scientists suggested two technologies viz., inter-cultivation of high yielding dry land grass and legumes together and growing dryland improved grass, legumes and fodder trees in the field as most appropriate in dry land conditions. Similarly, 7 scientists suggested that cultivating high yielding dry land fodder crops viz., Brachiaria decumbense, Pennisetum tri specific hybrid, perennial fodder sorghum (COFS-2) was the appropriate method to improve livestock production. Growing only improved grass like Signal on bunds is regarded as appropriate and less appropriate by equal number of scientists. The mixture of grass and legumes would help to supply quality fodder. Growing of fodder trees is viewed positively as it would suffice the fodder requirement in summer and requires less inputs and management. The results were similar to the results obtained by Itnal et al., (1989) and Channakeshava et al., (1993). 
Table.1 General description of the selected study villages

\begin{tabular}{|c|c|c|c|c|c|c|c|c|c|}
\hline \multirow{2}{*}{$\begin{array}{l}\text { Sl. } \\
\text { No. }\end{array}$} & \multirow[t]{2}{*}{ Particulars } & \multicolumn{4}{|c|}{ Rural } & \multicolumn{4}{|c|}{ Peri-urban } \\
\hline & & Hirebagewadi & Ankalagi & Basapura & Muthnal & Kakthi & Kadoli & Alarwad & Hindalga \\
\hline \multirow[t]{5}{*}{1.} & General information & & & & & & & & \\
\hline & Total geographical area in ha & 2160.00 & 1326.00 & 230.00 & 592.00 & NA & 1862.00 & 320.00 & NA \\
\hline & Total cultivable area & 1414.00 & 1244.00 & 229.00 & 582.00 & NA & 1738.00 & 274.00 & NA \\
\hline & Total population & 10024.00 & 3915.00 & 1223.00 & 1957.00 & 9546.00 & 8741.00 & 1732.00 & 9282.00 \\
\hline & Total no. of agricultural families & 79.00 & 142.00 & 81.00 & 237.00 & 57.00 & NA & 282.00 & 1104.00 \\
\hline \multirow[t]{6}{*}{2.} & Agriculture related information & & & & & & & & \\
\hline & Marginal landholdings in ha & 732.00 & NA & NA & 286.00 & 768.00 & 398.00 & 130.00 & 180.00 \\
\hline & Small landholdings in ha & 370.00 & 500.00 & NA & 314.00 & 160.00 & 809.00 & 90.00 & 214.00 \\
\hline & Big landholdings in ha & NA & 246.00 & NA & 816.00 & 70.00 & 530.00 & 17.00 & 31.00 \\
\hline & Total area under cereals & 870.00 & 253.00 & 230.00 & 1108.00 & 525.00 & 1015.00 & 375.00 & 257.00 \\
\hline & Total area under pulses & 1287.00 & 1968.00 & 229.00 & 835.00 & 803.00 & 1015.00 & 461.00 & 358.00 \\
\hline \multirow[t]{4}{*}{3.} & $\begin{array}{l}\text { Animal husbandry related } \\
\text { information }\end{array}$ & & & & & & & & \\
\hline & Number of cattle & 5556.00 & 1061.00 & NA & 1126.00 & 550.00 & 957.00 & 156.00 & 215.00 \\
\hline & Number of buffaloes & 3100.00 & 908.00 & NA & 287.00 & 1080.00 & 1029.00 & 150.00 & 520.00 \\
\hline & Average milk production (ltrs) & 40.00 & 101.00 & NA & 200.00 & 1350.00 & 200.00 & 235.00 & NA \\
\hline
\end{tabular}

NA - Data not available 
Table.2 Fodder technological options for improving livestock production system in the study area $n=10$

\begin{tabular}{|c|c|c|c|c|}
\hline Sl. No. & Technological options & $\begin{array}{c}\text { Most } \\
\text { appropriate }\end{array}$ & Appropriate & $\begin{array}{c}\text { Less } \\
\text { appropriate }\end{array}$ \\
\hline & Irrigated conditions & & & \\
\hline 1. & $\begin{array}{l}\text { Cultivation of only improved hybrid } \\
\text { Napier grass in the field }\end{array}$ & 0 & 4 & 6 \\
\hline 2. & $\begin{array}{l}\text { Cultivation of improved guinea grass } \\
\text { in the orchard }\end{array}$ & 4 & 5 & 1 \\
\hline 3. & $\begin{array}{l}\text { Inter cultivation of hybrid Napier grass } \\
\text { with perennial legumes (eg. Lucerne) }\end{array}$ & 6 & 3 & 1 \\
\hline 4. & $\begin{array}{l}\text { Inter cultivation of hybrid Napier grass } \\
\text { with annual fodder legumes (fodder } \\
\text { cowpea, fodder horsegram, etc.) }\end{array}$ & 2 & 4 & 4 \\
\hline 5. & $\begin{array}{l}\text { Intercultivation of improved perennial } \\
\text { grasses and improved perennial } \\
\text { legumes }\end{array}$ & 8 & 1 & 1 \\
\hline 6. & $\begin{array}{l}\text { Cultivation of improved perennial } \\
\text { grasses and also annual fodder crops } \\
\text { like sorghum, maize in the field }\end{array}$ & 2 & 6 & 2 \\
\hline \multirow[t]{2}{*}{7.} & $\begin{array}{l}\text { Cultivation of improved annual fodder } \\
\text { crops in combination with annual } \\
\text { fodder legumes }\end{array}$ & 3 & 5 & 2 \\
\hline & Dry land condition & & & \\
\hline 1. & $\begin{array}{l}\text { Growing improved grass like } \\
\text { Brachiaria decumbense (Signal grass) } \\
\text { on bunds }\end{array}$ & 2 & 4 & 4 \\
\hline 2. & $\begin{array}{l}\text { Growing Brachiaria decumbense + } \\
\text { Stylosanthes spp. On bunds }\end{array}$ & 4 & 5 & 1 \\
\hline 3. & $\begin{array}{l}\text { Cultivating high yielding dry land } \\
\text { fodder crops Brachiaria decumbense, } \\
\text { Pennisetun tri specific hybrid, } \\
\text { perennial fodder sorghum (COFS-2) in } \\
\text { the field }\end{array}$ & 3 & 7 & 0 \\
\hline 4. & $\begin{array}{l}\text { Inter cultivation of high yielding dry } \\
\text { land grass and legumes together }\end{array}$ & 7 & 2 & 1 \\
\hline 5. & $\begin{array}{l}\text { Cultivation of annual fodder crops } \\
\text { only like fodder sorghum, maize in } \\
\text { kharif }\end{array}$ & 1 & 6 & 3 \\
\hline 6. & $\begin{array}{l}\text { Growing of fodder trees like subabul, } \\
\text { glyricidia around the farms }\end{array}$ & 2 & 6 & 2 \\
\hline 7. & $\begin{array}{l}\text { Growing dryland improved grass, } \\
\text { legumes and fodder trees in the field }\end{array}$ & 7 & 2 & 1 \\
\hline
\end{tabular}


Table.3 Constraints expressed by the respondents in fodder management $n=160$

\begin{tabular}{|c|l|c|c|c|c|}
\hline \multirow{2}{*}{$\begin{array}{l}\text { SI. } \\
\text { No }\end{array}$} & \multicolumn{1}{|c|}{ Particulars } & \multicolumn{2}{c|}{ Rural } & \multicolumn{2}{c|}{ Peri-urban } \\
\hline 1. & Lack of scientific knowledge in fodder & No & $\%$ & No & $\%$ \\
\hline & cultivation & 32 & 40.00 & 2 & 2.50 \\
\hline 2. & Carrying fodder manually in rainy season & 30 & 37.50 & 5 & 6.25 \\
\hline 3. & Lack of space for proper storage & 25 & 31.25 & 5 & 6.25 \\
\hline 4. & High transportation cost & 12 & 15.00 & 33 & 41.25 \\
\hline 5. & Scarcity of green fodder & 12 & 15.00 & 28 & 35.00 \\
\hline 6. & Scarcity of labour & 5 & 6.25 & 27 & 33.75 \\
\hline 7. & High labour charges & 2 & 2.50 & 17 & 21.25 \\
\hline 8. & High fodder cost & 1 & 1.25 & 22 & 27.5 \\
\hline
\end{tabular}

Multiple problems are possible

Table.4 Relationship between selected independent variables with economic performance $n$ $=160$

\begin{tabular}{|c|c|c|c|c|}
\hline \multirow{2}{*}{$\begin{array}{l}\text { SI. } \\
\text { No }\end{array}$} & Variables & \multicolumn{3}{|c|}{ Economic performance } \\
\hline 1 & & Rural (r) & Peri-urban (r) & Total (r) \\
\hline 2 & Age & -0.054 & 0.04 & 0.0158 \\
\hline 3 & Education & 0.125 & 0.07 & $0.25^{* *}$ \\
\hline 4 & Land holding & 0.183 & 0.06 & $0.251^{*}$ \\
\hline 5 & Herd size & 0.122 & 0.001 & -0.125 \\
\hline 6 & Milk volume & 0.134 & -0.02 & -0.038 \\
\hline 7 & Income from agriculture & 0.120 & 0.054 & 0.102 \\
\hline 8 & Income from livestock & $0.286^{* *}$ & 0.126 & -0.058 \\
\hline$*$ & Feeding index & $0.502 * *$ & 0.174 & $0.182 *$ \\
\hline$*$ & Significant at 5\% level & & & \\
\hline
\end{tabular}

Table value at $1 \%$ is 0.283 and at $5 \%$ is 0.217

\section{Constraints in fodder management}

The results presented in Table 3 indicate the constraints perceived by farmers in fodder management. It can be observed from the table that, lack of scientific knowledge in fodder cultivation was expressed as major constraint by most of the farmers (40.00) in rural area. The fodder crops receive last priority be it for cultivation by the farmers or for training or extension programs by the extension agencies. While state agriculture departments concentrate on extending technologies of major crops of the area, the state department of animal husbandry emphasis as on clinical or veterinary aspects of livestock. Thus, extension of fodder technological knowhow is suffering. In periurban area most of the respondents $(41.25 \%)$ expressed high transportation cost as the major constraint. Livestock owners in this area purchase large quantities of fodder as 
was found in the study. Many times cost of the transportation was found to be more than the actual cost of dry fodder. The other major constraints expressed by rural people were, carrying fodder manually in rainy season (37.5\%), lack of space for proper storage of fodder $(31.25 \%)$. In peri-urban area the other constraints expressed by respondents were scarcity of green fodder $(35.00 \%)$ and scarcity of labour $(33.75 \%)$. Similar findings were reported by Thorat et al., (1994).

\section{Relationship between selected independent variables with fodder management}

Income from livestock and feeding index were positively and significantly related with economic performance (Table 4) in rural areas. There was no significant relationship observed with other variables. In peri-urban area there was no significant relationship found between economic performance and any of the variables studied. When considered rural and peri urban area together, variables education, land holding and feeding index were positively and significantly related with economic performance.

\section{References}

Government of India Planning Commission. http://dahd.nic.in /stat-files/table20. htm.

Itnal, C.J., Dixit, L.A. and Patil, S.V., 1989, Forage production as influenced by fodder species and Alley widths in an Alley cropping system. Karnataka Journal of Agricultural Sciences, 2 (4): 265-272.

Channakeshava, B.C., Ramachandrappa, B.K. and Dwarakinath, N., 1993, Performance of Anjan grass (Cenchus ciriaris) in pure and mixed (Stylosanthes hamata) stand under different fertility levels in rainfed situation. Mysore Journal of Agricultural Science, 27: 33-36.

Thorat, D.R. and Kulkarni, B.R., 1994, Constraints faced by the dairy farmers. Maharashtra Journal of Extension Education, 13: 305-306.

\section{How to cite this article:}

Pushpa, P., B. S. Lakshman Reddy, Jayalakshmi B. Pawar, K. Chandan and Gurumurthy, S. B. 2020. A Study on Fodder Technological Options for Improving Livestock Production in Karnataka. Int.J.Curr.Microbiol.App.Sci. 9(11): 2792-2798. doi: https://doi.org/10.20546/ijcmas.2020.911.338 